\title{
Anti-FGFR4 Monoclonal Antibody U3-1784
}

National Cancer Institute

\section{Source}

National Cancer Institute. Anti-FGFR4 Monoclonal Antibody U3-1784. NCI Thesaurus.

Code C126334.

A human monoclonal antibody against human fibroblast growth factor receptor 4 (FGFR4), with potential antineoplastic activity. Upon administration, U3-1784 specifically binds to and blocks FGFR4. This prevents the activation of FGFR4, inhibits FGFR4mediated signaling and leads to an inhibition of cell proliferation in FGFR4-overexpressing tumor cells. FGFR4, a receptor tyrosine kinase overexpressed by certain tumor cell types, is involved in tumor cell proliferation, differentiation, angiogenesis, and survival. 